\title{
Koliko se otvoreno i odgovorno trošio proračunski novac za ublažavanje koronakrize
}

Franić, Josip; Bronić, Mihaela

Source / Izvornik: Osvrti Instituta za javne financije, 2021, 14, 1 - 6

Journal article, Published version

Rad u časopisu, Objavljena verzija rada (izdavačev PDF)

https://doi.org/10.3326/ao.2021.118

Permanent link / Trajna poveznica: https:/urn.nsk.hr/urn:nbn:hr:242:795420

Rights / Prava: Attribution-NonCommercial-NoDerivatives 4.0 International/ImenovanjeNekomercijalno-Bez prerada 4.0 međunarodna

Download date / Datum preuzimanja: 2023-04-26

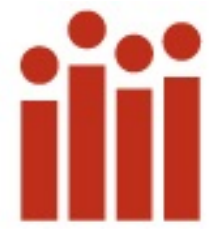

Institute of Public Finance Repository

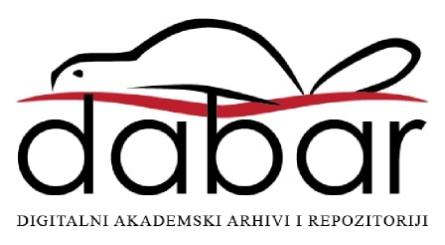



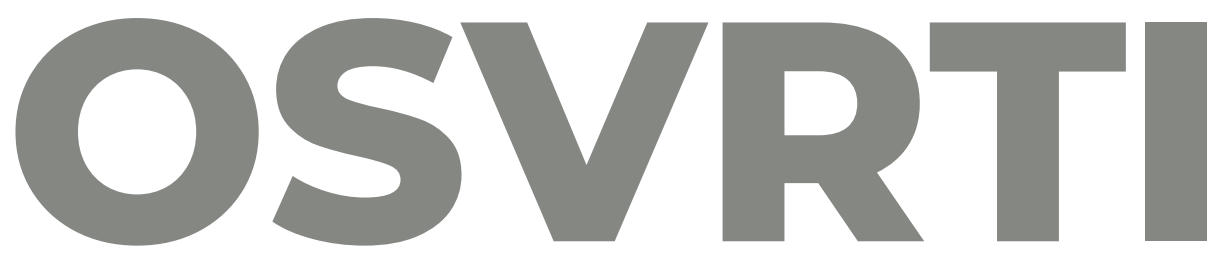

\section{Instituta za javne financije}

\section{Koliko se otvoreno i odgovorno trošio proračunski novac za ublažavanje koronakrize?}

Josip Franić, Mihaela Bronić

Institut za javne financije, Zagreb

International Budget Partnership objavio je rezultate istraživanja o otvorenosti i odgovornosti u trošenju sredstava iz proračuna središnje države za ublažavanje koronakrize. Istraživanje obuhvaća 120 država u razdoblju od 1. ožujka do 30. rujna 2020., a među njima je i Hrvatska, koja je pri provedbi fiskalnih mjera namijenjenih ublažavanju zdravstvenih i gospodarskih posljedica koronakrize djelomično zadovoljila međunarodne standarde pravovremenog informiranja i uključivanja zainteresiranih dionika. Stoga bi Vlada i Sabor trebali osigurati što otvorenije i kvalitetnije donošenje i provođenje kriznih mjera. Primjerice, kada je to moguće, sve detalje o ugovorima vezanim uz javnu nabavu trebalo bi objavljivati u strojno čitjivom formatu na mrežnim stranicama. Također je nužno omogućiti sudjelovanje javnosti u oblikovanju, odobravanju i provedbi kriznih mjera. 
Prema procjeni Međunarodnog monetarnog fonda, fiskalne intervencije u zdravstvene sustave i gospodarstva izazvane koronakrizom (dalje u tekstu krizne mjere) samo su do kraja 2020. dosegle 14 bilijuna dolara. lako u pravilu opravdane, ove intervencije sa sobom nose i značajne rizike vezane uz nerazborito i netransparentno trošenje javnih sredstava. Kako bi utvrdio do koje su razine postupci donošenja, izvršavanja i nadzora kriznih mjera bili u skladu s međunarodno prihvaćenim standardima otvorenosti proračuna, International Budget Partnership, neprofitna organizacija sa sjedištem u Washingtonu, detaljno je analizirao oko 400 fiskalnih kriznih paketa donesenih između 1. ožujka i 30. rujna 2020. u 120 zemalja diljem svijeta.

Istraživanje se temeljilo na 26 pokazatelja podijeljenih u tri skupine s ciljem pronalaženja odgovora na sljedeća pitanja: 1) koliko su središnje vlasti bile transparentne pri donošenju i izvršavanju kriznih mjera; 2) do koje su razine nacionalni parlamenti i uredi za reviziju bili uključeni u tom procesu te;

3) je li široj javnosti pružena adekvatna mogućnost sudjelovanja. ${ }^{2}$

\footnotetext{
1 Istraživanje je isključivo fokusirano na sredstva osigurana u proračunu središnje države, što uključuje izravne financijske potpore, porezne olakšice te sve fiskalne mjere vezane uz kreditiranje i druge načine osiguranja likvidnosti. Mjere središnjih banaka, kao i one regionalnih i lokalnih vlasti, nisu obuhvaćene ovim istraživanjem.

2 Detaljnije objašnjenje metodologije možete pročitati ovdje.
} 
Tablica 1. Otvorenost proračuna središnje države pri ublažavanju koronakrize ${ }^{3}$

\begin{tabular}{|c|c|c|}
\hline $\begin{array}{l}\text { Razina } \\
\text { otvorenosti }\end{array}$ & $\begin{array}{c}\text { Ukupan broj } \\
\text { država unutar } \\
\text { kategorije }\end{array}$ & Države \\
\hline Iznimna & 0 & - \\
\hline Odgovarajuća & 4 & Australija, Filipini, Norveška, Peru \\
\hline Djelomična & 29 & $\begin{array}{l}\text { Brazil, Bugarska, Čile, Dominikanska } \\
\text { Republika, Fidži, Francuska, Hrvatska, } \\
\text { Njemačka, Indonezija, Italija, Jamajka, } \\
\text { Japan, Južnoafrička Republika, Kanada, } \\
\text { Kirgistan, Kolumbija, Kostarika, Malezija, } \\
\text { Mongolija, Novi Zeland, Paragvaj, Poljska, } \\
\text { Portugal, Sijera Leone, Slovačka, Slovenija, } \\
\text { Švedska, Ujedinjeno Kraljevstvo, SAD }\end{array}$ \\
\hline
\end{tabular}

Afganistan, Argentina, Armenija, Azerbajdžan, Bangladeš, Bocvana, Benin, Bolivija, Bosna i Hercegovina, Češka, Egipat, Ekvador, Gana, Gruzija, Gvatemala, Honduras, Jordan, Južna Koreja, Kamerun, Kazahstan, Kenija, Kina, Lesoto, Liberija, Madagaskar, Mali, Maroko, Ograničena $56 \quad$ Meksiko, Moldavija, Mozambik, Namibija, Nepal, Niger, Nigerija, Nikaragva, Obala Bjelokosti, Pakistan, Papua Nova Gvineja, Ruanda, Rumunjska, Rusija, Salvador, Senegal, Sjeverna Makedonija, Somalija, Srbija, Sveti Toma i Principe, Španjolska, Šri Lanka, Tajland, Timor-Leste, Togo, Trinidad i Tobago, Ukrajina, Vijetnam, Zambija

Albanija, Alžir, Angola, Burkina Faso, Burundi, Čad, DR Kongo, Ekvatorska Gvineja, Etiopija, Gambija, Indija, Irak, Minimalna 31 Jemen, Južni Sudan, Katar, Kambodža, Komori, Libanon, Mađarska, Malavi, Mjanmar, Saudijska Arabija, Sudan, Svazi, Tadžikistan, Tanzanija, Tunis, Turska, Uganda, Venezuela, Zimbabve

Izvor: IBP (2021)

3 Konačni rezultati, dobiveni računanjem udjela potvrdnih odgovora u skupu pitanja koja se odnose na svaki od tri spomenuta segmenta otvorenosti proračuna, zbog lakšeg su razumijevanja prikazani u opisnom obliku. Za detalje vidjeti metodologiju. 
Premda je u uvjetima iznenadnog šoka i urgentne potrebe za financijskim intervencijama bilo nerealistično očekivati iznimnu razinu otvorenosti, rezultati prikazani u Tablici 1 pokazuju da su jedino Australija, Filipini, Norveška i Peru svojim građanima pružili odgovarajuću količinu proračunskih informacija i osigurale odgovarajuću ulogu svih dionika. Hrvatska se, zajedno s većinom analiziranih članica EU-a, nalazi u skupini država koje su djelomično zadovoljile međunarodne standarde otvorenosti proračuna pri donošenju i izvršavanju kriznih mjera. S druge strane, gotovo tri četvrtine država pokazale su ograničenu ili minimalnu razinu otvorenosti.

Tablica 2. Otvorenost proračuna središnje države pri ublažavanju koronakrize u Hrvatskoj

Područje otvorenosti proračuna

\section{TRANSPARENTNOST}

Donošenje kriznih mjera

Makroekonomski i proračunski pokazatelji na kojima se temelje krizne mjere

Detalji o pojedinačnim mjerama

Primatelji potpore i rezultati Izvori financiranja Izvanproračunski fondovi

Provedba kriznih mjera

Izvješća o provedbi

Izvanproračunski fondovi

Javna nabava

Područje otvorenosti proračuna

NADZOR

Uloga Sabora

Uloga Državnog ureda za reviziju

UKLJUČENOST

Sudjelovanje javnosti
Razina dostupnosti informacija

ODGOVARAJUĆA

Odgovarajuća

Iznimna

Iznimna

Djelomična

Djelomična

Minimalna

Odgovarajuća

Odgovarajuća

Iznimna

Ograničena

Uloga analiziranih dionika

OGRANIČEN

Djelomična

Minimalna

MINIMALNA

Minimalna

Napomena: Minimalna otvorenost 0 - 0,2 boda; ograničena otvorenost 0,21

- 0,4 boda; djelomična otvorenost 0,41 - 0,6 bodova; odgovarajuća

otvorenost 0,61 - 0,8 bodova; iznimna otvorenost 0,81 - 1,0 bod.

Izvor: IBP (2021) 
Ovakav ishod za Hrvatsku u prvom je redu rezultat odgovarajuće količine pruženih informacija o samim kriznim mjerama koje je Vlada donijela tijekom ožujka i travnja 2020. (Tablica 2). Time su djelomično kompenzirani lošiji rezultati kad je riječ o ulozi institucija zaduženih za nadzor donošenja i provedbe kriznih mjera te minimalnoj participaciji zainteresirane javnosti u donošenju i provedbi.

Kako bi se u budućnosti osiguralo što otvorenije i kvalitetnije donošenje i provedba kriznih mjera - jer kvaliteta mjera uvelike ovisi o informiranosti i uključenosti svih dionika u proces njihova donošenja - Vladi i Saboru mogli bi pomoći sljedeći primjeri dobre prakse koje ističe istraživanje:

- U SAD-u je izrađena mrežna stranica "Nadzor pandemije" koja između ostaloga omogućuje detaljan uvid u 19 kriznih programa, uključujući podatke o rashodima.

- U Ekvadoru, Agencija za javnu nabavu omogućuje otvoren pristup podatcima o svim ugovorima vezanim uz javnu nabavu na mrežnoj stranici "Hitna javna nabava".

- U Sierra Leoneu, Državni ured za reviziju objavio je revizijski izvještaj o rashodima za ublažavanje koronakrize, na temelju kojeg je Antikorupcijska agencija mogla provesti niz istraga koje su rezultirale i uhićenjima.

- Norveška je zemlja u kojoj su izvršna i zakonodavna vlast provele odgovarajuće konzultacije s ključnim dionicima tijekom formulacije i provedbe kriznih paketa. 
Nadalje, Vlada i Sabor mogli bi poboljšati otvorenost i odgovornost pri donošenju i provedbi kriznih mjera na način da: (1) objavljuju mjesečne podatke o provedbi svake pojedine postojeće mjere; (2) objavljuju u strojno čitljivom formatu na svojim mrežnim stanicama kada je to moguće sve detalje o ugovorima vezanim uz javnu nabavu; (3) potiču Državni ured za reviziju da u što kraćem razdoblju provodi revizije vezane uz krizne mjere; (4) omogućuju odgovarajuće načine participacije javnosti u formulaciji, odobravanju i provedbi kriznih mjera. 